\title{
Artikel
}

\section{Toekomstbestendig mededingingsrecht}

\author{
Anna Gerbrandy*
}

\section{Inleiding}

Ik houd van sciencefiction. De kern van dat genre ligt in technologische ontwikkelingen die in de toekomst mogelijk zouden kunnen zijn. Dat levert vervolgens vaak vragen op hoe de maatschappij zich met die technologische ontwikkelingen moet verhouden. Een voorbeeld van een dergelijk verhaal is het al in 1941 geschreven Nightfall, waarin auteur (en wetenschapper) Asimov een wereld centraal stelt waar het nooit donker is. ${ }^{1}$ Omdat er altijd wel enkele van de zes zonnen aan de hemel staan, is in het collectieve bewustzijn van de inwoners een sterke angst voor het donker aanwezig. In de periode dat het verhaal speelt, leiden archeologen uit nieuwe opgravingen af dat er ongeveer elke 2000 jaar een wereldomspannend en allesvernietigend vuur woedt; en een jonge astronoom leidt uit de banen van de zonnen af dat er zich binnenkort een totale zonnenverduistering zal voordoen. Dat tergt de verbeelding, maar hij en zijn collega's roepen de bewoners op tot voorbereiding op deze eclips. Toch kan uiteindelijk niemand zich een voorstelling maken van het psychologisch effect van het donker, en zeker niet van de beangstigende sterrenhemel die dan voor het eerst in 2049 jaar zichtbaar wordt en waarmee het gekmakende besef binnendringt dat de eigen zes zonnen niet de enige zonnen zijn, maar dat zich daar- achter een onmetelijk heelal uitstrekt. Natuurlijk volgt totale chaos - een deel van de wetenschappers moet het ontgelden - en natuurlijk volgt het onbedwingbare vuur dat wordt aangestoken om de duisternis tegen te gaan. De relevantie van dit verhaal voor mijn betoog is ten eerste dat het onmogelijk is om een goede voorstelling te maken van de toekomst. Toch moet de maatschappij - en dus ook het recht - voor zo veel als mogelijk zo worden ingericht dat ze toekomstbestendig is. Ten tweede is relevant dat wetenschap daarin een belangrijke rol kan spelen. ${ }^{2}$ De titel van dit artikel (en mijn oratie) is derhalve 'Toekomstbestendig mededingingsrecht'. Dat is mededingingsrecht dat relevantie behoudt omdat het zich verhoudt tot maatschappelijke ontwikkelingen, inclusief ontwikkelingen die we in de toekomst verwachten. Hieraan ligt ten grondslag dat het recht niet op zichzelf staat, maar zich dient te verhouden tot zijn maatschappelijke context: recht dient responsief te zijn. ${ }^{3}$ Tegelijkertijd is het recht er niet alleen om kortetermijnoplossingen te genereren, en ook moet het niet te gemakkelijk van gedaante wisselen. ${ }^{4}$ Ook daarom is het belangrijk te blijven constateren dat het recht in dienst staat van een hogere doelstelling: het bewerkstelligen van rechtvaardigheid.

Voor het mededingingsrecht is het de vraag of het niet te ver van zowel maatschappelijke context als hoger doel dreigt weg te raken.

Wat die context betreft, dient het mededingingsrecht zich in ieder geval te verhouden tot het vrijwel onontkoombaar geworden streven naar een duurzame maat-
Prof. mr. A. Gerbrandy is hoogleraar Mededingingsrecht aan de Universiteit Utrecht. Dit artikel is voor een groot deel gelijk aan de tekst van de inaugurele rede die zij uitsprak op 4 april 2016 bij de aanvaarding van het ambt van hoogleraar Mededingingsrecht. Laurens van Kreij wordt hartelijk bedankt voor zijn hulp bij het omwerken van de oratietekst naar deze publicatie.

1. Origineel: I. Asimov, 'Nightfall', Astounding Science-Fiction (28) 1941, afl. 1, p. 9-34; later opnieuw uitgegeven in boekvorm: I. Asimov en R. Silverberg, Nightfall, New York: Bantam Books 1991.
2. En ten derde: dat wetenschappers het niet per se hoeven te ontgelden, mits ook zij toekomstbestendig zijn.

3. Zie P. Nonet en P. Selznick, Law and Society in Transition: towards responsive law, New York: Harper \& Row 1978.

4. Recht moet in zekere zin ook conservatief zijn, vanwege het fundamentele belang van rechtszekerheid en rechtsgelijkheid. 
schappij en een duurzame economie. ${ }^{5}$ Hoewel er niet per se consensus bestaat over de achterliggende probleemanalyse of over de oplossingsrichtingen, stel ik hier de redenen voor verduurzaming niet verder ter discussie. Ook zijn er verschillende toekomstscenario's: van een op circulaire economie gebaseerde maatschappij, of een postkapitalistische samenleving, tot aan donkere postapocalyptische voorspellingen toe. ${ }^{6} \mathrm{Er}$ zijn nog andere belangrijke maatschappelijke ontwikkelingen die voor mijn betoog relevant zijn en waarop ik in de loop daarvan terug zal komen: (1) de versterking van de ethische verplichting voor ondernemingen tot maatschappelijk verantwoord ondernemen, ${ }^{7}$ (2) globalisering, ${ }^{8}$ en (3) de veranderde verhouding tussen markt en overheid

5. Zie vooral G.H. Brundtland, Our Common Future: The World Commission on Environment and Development, New York: Oxford University Press 1987; en verder voor de nationale context o.a. het streven om van Nederland in 2030 de leidende circulaire economie te maken: het programma 'Van Afval naar Grondstoffen (VANG)', van het ministerie van Infrastructuur en Milieu, Rijksoverheid.nl (zoek op verantwoord omgaan met afval en grondstoffen); en Nederland als 'Circular hotspot': Netherlandscircularhotspot.nl; op EU-niveau ook: Mededeling van de Commissie van 19 juni 2001, Duurzame ontwikkeling in Europa voor een betere wereld: Een strategie van de Europese Unie voor duurzame ontwikkeling, COM/2001/264 def.; Europese Commissie, Manifesto for a resource-efficient Europe, MEMO/2012/989); en Mededeling van de Commissie van 3 maart 2010, EUROPA 2020. Een strategie voor slimme, duurzame en inclusieve groei, COM/2010/2020 def.

6. Sciencefiction lezen vergroot absoluut het inzicht in de consequenties hiervan, met name als het gaat om postindustriële dystopias (o.a. William Gibson's boeken) en postapocalyptische scenario's (waaronder het aangrijpende The Road van Cormac McCarthy (Londen: Picador 2009), en de postapocalyptische boeken van Margaret Atwood). Voor non-fictie over deze thema's, zie over circulaire economie al in 1980: H.E. Daly, Economics, ecology, ethics: essays towards a steady state economy, San Francisco: W.H. Freeman 1980; over postkapitalisme o.a. P. Mason, Postcapitalism, A Guide to our Future, Londen: Penguin 2015 (en voor een korte versie: P. Mason, 'The end of capitalism has begun', The Guardian 17 juli 2015, <Theguardian.com> (zoek op postcapitalism); en oproepend tot het bewerkstelligen van een postapocalyptisch einde aan industrialisatie: A. McBay, L. Keith en D. Jensen, Deep Green Resistance: Strategy to Save the Planet, New York: Seven Stories Press 2011. Over of sciencefiction economisch verval kan voorkomen: D. Walter, 'Can science fiction lead us away from economic collapse?', The Guardian 1 december 2011.

7. Voor een overzicht zie: A. Crane e.a., The Oxford Handbook of Corporate Social Responsibility, Oxford: Oxford University Press 2001; en ook E. Garriga en D. Mele, 'Corporate Social Responsibility Theories: Mapping the Territory', Journal of Business Ethics (53) 2004, afl. 1, p. 51-71. Over de stakeholder theory: R.E. Freeman, 'A Stakeholder Theory of the Modern Corporation', in: T.L. Beauchamp en N.E. Bowie (red.), Ethical Theory and Business, Upper Saddle River: Pearson Prentice Hall 2004, p. 55-64, als antwoord op het idee van shareholdervalue (M. Friedman, 'The Social Responsibility of Business Is to Increase Its Profits', The New York Times Magazine 13 september 1970. Een alternatief biedt: J. Heath, Morality, competition and the firm. The market failures approach to business ethics, Oxford: Oxford University Press 2014; zie ook: W. Norman, 'Business Ethics as Self-Regulation. Why Principles That Ground Regulations Should Be Used to Ground Beyond-Compliance Norms as Well', Journal of Business Ethics (102) 2011, afl. 1, p. 43-57; maar ook L. Sacconi, M. Blair, R.E. Freeman en A. Vercelli (red.), Corporate Social Responsibility and Corporate Governance. The Contribution of Economic Theory and Related Disciplines, New York: Palgrave Macmillan 2011; en nog een alternatief biedt V. Vanberg, "Corporate social responsibility and the "game of catallaxy". The perspective of constitutional economics', Constitutional Political Economy (18) 2007, afl. 3, p. 199-222. in het waarborgen van het publiek belang. ${ }^{9}$ Ook zonder te weten welke kant het precies opgaat, kan het recht, dus ook het mededingingsrecht, deze ontwikkelingen niet negeren.

Het is vervolgens in deze context dat ook de vraag wat rechtvaardigheid voor het mededingingsrecht betekent, aan de orde moet komen.

Ik zal uiteindelijk een van de wijzen schetsen waarop het mededingingsrecht op deze veranderde omstandigheden zou kunnen reageren. Daaraan voorafgaand zal ik eerst laten zien waarom deze ontwikkelingen überhaupt een mededingingsrechtelijk dilemma opleveren.

\section{Mededingingsrechtelijk probleem}

Stel, u staat in een Fries weidelandschap. Het is lente dus u hoort vogels, zoals de kievit en grutto. Of eigenlijk: u hoort ze misschien wel niet, omdat door intensieve beweiding het leefgebied van de kievit en grutto is verminderd. Dat vinden zowel vogelliefhebbers als veel boeren een gemis. Dus kan er een initiatief ontstaan waarin melkveehouders gezamenlijk besluiten anders - weidevogelvriendelijk - te boeren. ${ }^{10}$ Stel dat de grotere melkcoöperaties interesse zouden hebben in dit initiatief. Een dergelijke samenwerking levert echter hogere productiekosten op en dat kan leiden tot een hogere prijs. Ik schets het hier wat kort, maar het zal u duidelijk zijn dat dit - potentieel - een mededingingsrechtelijk probleem oplevert. Stelt u zich ook eens voor dat u een jonge fabrieksarbeidster bent op het zuidelijke platte-

8. Over globalisering zijn boekenkasten vol geschreven, waaronder J.E. Stiglitz, Globalization and its discontents, New York: W.W. Norton 2002. Over de link tussen globalisering en csr: A.G. Scherer en G. Palazzo, 'Globalization and Corporate Social Responsibility', in: A. Crane e.a., The Oxford Handbook of Corporate Social Responsibility, Oxford: Oxford University Press 2001, p. 413-432.

9. Zie o.a. M. Moran, 'Understanding the Regulatory State', British Journal Political Science (32) 2002, afl. 2, p. 391-413; J. Gingritch, Making Markets in the Welfare State. The Politics of Varying Market Reforms, Cambridge: Cambridge University Press 2011; S.I. Benn en G.F. Gaus, 'The Liberal Conception of the Public and the Private', in: S.I. Benn en G.F. Gaus, Public and Private in Social Life, London: Croom Helm 1983; J. Weintraub, 'The Theory and Politics of the Public/Private Distinction', in: J. Weintraub en K. Kumar, Public and Private in Thought and Practice. Perspectives on a grand dichotomy, Chicago \& London: The University of Chicago Press; A. Stark, Drawing the Line. Public and Private in America, Washington: The Brookings Institution 2010; en in algemene zin: G. Stoker, Governance as theory. Five propositions, UNESCO 1998; P. Pattberg, 'The Institutionalization of Private Governance. How Business and Nonprofit Organizations Agree on Transnational Rules', Governance (18) 2005, afl. 4, p. 589-610; met een andere invalshoek: R. Shamir, 'The age of responsibilization. On market-embedded morality', Economy and Society (37) 2008, afl. 1, p. 1-19. Liberalisering is onderwerp van o.a. G. Majone, 'The rise of the regulatory state in Europe', West European Politics (17) 1994, afl. 3, p. 77-101; voor kritiek o.a. C. Crouch, The Strange Non-Death of Neoliberalism, Cambridge: Polity Press 2011; C. Cordelli, 'The Institutional Division of Labor and the Egalitarian Obligations of Non-Profits', Journal of Political Philosophy (20) 2012, afl. 2, p. 131-155.

10. Zie bijvoorbeeld 'Boerengilde kansrijker dan biologisch', Leeuwarder Courant 15 februari 2014. 
land van India. U werkt in een kledingfabriek waar shirts en broeken in elkaar worden gezet die in de Europese Unie onder verschillende bekende merknamen worden verkocht. $U$ maakt lange dagen in slechte omstandigheden en $\mathrm{u}$ verdient weinig. Om daarin verandering te brengen nemen de merkondernemingen het initiatief om met de fabriekseigenaar afspraken te maken voor betere arbeidsomstandigheden en een hoger, eerlijker, loon: een 'living mage'. De financiering komt van de kledingmerken. ${ }^{11}$ Dat kan leiden tot een hogere prijs voor een vestje of trui in de EU, wat - potentieel - een mededingingsrechtelijk probleem oplevert.

Dergelijke initiatieven hebben (ten minste) twee elementen gemeen. $\mathrm{Zij}$ delen die met twee andere in Nederland bekende initiatieven: de Kip van Morgen over verduurzaming van de kippenhouderij, en het Energieakkoord, over de overgang naar duurzamere vormen van energie. ${ }^{12}$ Ten eerste zijn deze initiatieven in ieder geval mede gericht op een publiek belang, dat ik hier onder de noemer 'duurzaamheid' zal vangen. ${ }^{13}$ Ten tweede zijn het afspraken tussen ondernemingen die mededingingsbeperkend kunnen zijn omdat zij kunnen leiden tot een hogere consumentenprijs. Indien dat het geval is, stuiten ze op (de grenzen van) het mededingingsrecht.

Zoals bekend is het mededingingsrecht gericht op marktwerking en concurrentie. Marktwerking is over het algemeen een efficiënte manier om producten en diensten aan te bieden zonder dat consumenten daar te veel voor moeten betalen. Het is een spel van vraag en aanbod, waarbij de premisse is dat als dat spel volgens de regels wordt gespeeld de uitkomst het meest efficiënt zal zijn. Dus verbiedt het mededingingsrecht - als spelbederf - gedragingen van ondernemingen die de concurrentie beperken omdat die mededingingsbeperkende afspraken ('kartels') over het algemeen leiden tot prijsverhogingen. ${ }^{14}$ Net als veel beleidsterreinen kreeg het mededingingsrecht vanaf de jaren negentig een steviger economische grondslag: economische theorie werd de basis waarop het rechtssysteem rust. Sinds die tijd stelt de Europese Commissie, die toeziet op naleving van het Europese mededingingsrecht, bij een beoordeling het

11. Zie Fair Wear Foundation. Competition Law and Living Wages, Arnold \& Porter juni 2015, <Fairwear.nl> (zoek op Fair Wear Foundation Competition Law and Living Wages).

12. Zie over deze initiatieven berichtgeving zoals: Energieakkoord voor duurzame groei (rapport 6 september 2013), Den Haag: SER 2013, maar over de mededingingsrechtelijke analyse van ACM met name: Notitie ACM over sluiting 5 kolencentrales in SER Energieakkoord, Den Haag: ACM 2013, <Acm.nl/nl> (zoek op Notitie Energieakkoord); Analyse ACM van duurzaamheidsafspraken Kip van Morgen, Den Haag: ACM 2013, <Acm.nl/nl> (zoek op Analyse Kip van Morgen).

13. Duurzaamheid is een 'fuzzy concept' waarvan echter de kern wel is vast te stellen (voor de EU-definitie zie: <Ec.europa.eu/environment/ eussd/>).

14. Art. $101 \mathrm{VWEU}$ en art. $6 \mathrm{Mw}$. Het mededingingsrecht omvat natuurlijk ook nog andere normen; die blijven hier buiten beschouwing. begrip consumentenwelvaart centraal. ${ }^{15}$ De beoordeling volgt de juridische tekst: (1) Eerst wordt vastgesteld of er een mededingingsbeperkende afspraak is. Mededingingsbeperkingen zijn verboden (art. 101 lid 1 VWEU/ art. 6 lid $1 \mathrm{Mw}$ ). (2) Er is echter een uitzondering voor mededingingsbeperkende afspraken die ook leiden tot voordelen (art. 101 lid $3 \mathrm{VWEU} /$ art. 6 lid $3 \mathrm{Mw}$ ). Als de positieve effecten groter zijn dan de negatieve effecten, dan is de afspraak toegestaan. Daarbij ligt in de huidige interpretatie van het mededingingsrecht de nadruk op het kwantificeren van de daadwerkelijke effecten op consumentenwelvaart. ${ }^{16}$

Maar dit levert nu een probleem op: de bescherming van de grutto of het belang van werkneemsters in India is lastig te vangen in deze beoordelingsmethodiek. Net als de dierenwelzijnskwestie van de Kip van Morgen, de vermindering van schadelijke uitstoot van het Energieakkoord, en om enkele andere voorbeelden te noemen: het bevorderen van sociale cohesie of het in stand houden van de polderdialoog, ${ }^{17}$ de bescherming van de zuiverheid van het Friese paard, ${ }^{18}$ het tegengaan van leegstand in kantoorgebouwen, het beschermen van sociaal zwakkere groepen, het tegengaan van erosie van topsoil door langdurige investeringen in plantages, het bestrijden van comazuipen, of de bescherming van vakbondsvrijheid in Zuid-Amerika. ${ }^{19}$

Het Energieakkoord en het Kip van Morgen-initiatief werden gesmeed in coalities tussen marktpartijen en het maatschappelijk midden en met een zekere inmenging van de overheid. Toch stuitten beide initiatieven op een mededingingsrechtelijk 'nee' van de Nederlandse toezichthouder, ACM, hoewel ACM wel ook de positieve effecten van de afspraken berekende en daarmee de grenzen zocht binnen de consumentenwelvaartsbenadering. ${ }^{20}$ Het mededingingsrechtelijk 'nee' leverde vervolgens kritiek op. Zowel politiek - als er een breed draag-

15. Het een hoeft niet te leiden tot het ander: het is niet zo dat het centraal stellen van consumentenwelvaart een noodzakelijk gevolg is van een grotere invloed van economie op het mededingingsrecht. Zie: O. Budzinski, 'Monoculture versus Diversity in Competition Economics', Cambridge Journal of Economics 2008, afl. 2, p. 295-324; A. Pera, 'Changing View of Competition, Economic Analysis and EC Antitrust Law', European Competition Journal 2008, afl. 1, p. 127-168.

16. Het begrip 'consumentenwelvaart' is overigens niet eenduidig: zie daarover o.a. K. Cseres, 'The Controversies of the Consumer Welfare Standard', Competition Law Review (3) 2007, afl. 2, p. 121-173.

17. Zie over dit aspect van het energieakkoord ook J. Mulder, Social legitimacy in the internal market - a dialogue of mutual responsiveness (diss. Florence), Florence: European University Institute 2016.

18. Hof Arnhem 17 november 2009, ECLI:NL:GHARN:2009:BL7079 (De Nieuwe Heuvel B.V./Koninklijke Vereniging 'Het Friesch PaardenStamboek'). Zie ook J. Mulder, Finding the public interest, Wouters and the case of the Friesian Horse (Amsterdam Centre for Law and Economics Conference Paper), Amsterdam 2013, <Acle.uva.nl/events/ competition--regulation-meetings/conference-papers-9th-cr-meeting $-2013 . h t m l>$.

19. Voor de goede orde: het is niet zo dat initiatieven ter bescherming van deze belangen altijd een inbreuk op het verbod van het eerste lid zouden opleveren (ook niet bij de huidige beoordelingsmaatstaf). Alleen als dat wel zo is, komt een beoordeling onder de uitzondering aan de orde.

20. Notitie ACM over sluiting 5 kolencentrales in SER Energieakkoord, Den Haag: ACM 2013, <Acm.nl/nl> (zoek op Notitie Energieakkoord); Analyse ACM van duurzaamheidsafspraken Kip van Morgen, Den Haag: ACM 2013, <Acm.nl/nl> (zoek op Analyse Kip van Morgen). 
vlak is, hoe kan ACM deze afspraken dan toch veroordelen -, vanuit economische hoek - of de gebruikte methode wel juist was uitgevoerd en of daar wel de juiste conclusies aan werden verbonden - en ook in normatieve zin: is dit wel een aanvaardbare wijze om onverenigbare elementen tegen elkaar af te wegen? ${ }^{21}$

Het gaat hier immers om 'niet-economische belangen', die in essentie vreemd zijn aan datgene waar marktwerking om draait. ${ }^{22}$ Marktwerking heeft grote voordelen, maar is niet gebaseerd op samenwerking, niet gebaseerd op langetermijnvisies, ${ }^{23}$ en maakt zich niet druk om fairness of de rechtvaardigheid van de uitkomsten van het marktproces. ${ }^{24}$ Dus is het in het huidige mededingingsrecht bijvoorbeeld lastig om rekening te houden met de tipping-point gedachte, waarbij veel meer dan het behoud van alleen de grutto een rol speelt maar waarin het gaat om ecologisch evenwicht. ${ }^{25}$ Het is ook lastig om voordelen die ergens ánders terechtkomen, en dus niet bij degene die de hogere prijs betalen, in het schema in te passen. Denk aan de betere arbeidsomstandigheden voor de Indiase fabrieksmedewerkster die wij hier zouden betalen in de prijs van een truitje. ${ }^{26}$ Maar andersom is het überhaupt de vraag of wat de consument in Nederland overheeft voor de bescherming van de biodiversiteit van het regenwoud, de vakbondsvrijheid van mijnwerkers in Colombia, of living mages in India, de manier moet zijn om die belangen uit te drukken. ${ }^{27}$

21. Zo was ik uitgenodigd, tegelijk met o.a. bestuursvoorzitter van ACM Chris Fonteijn en andere deskundigen, voor een expertmeeting van de Vaste Kamercommissie voor Economische Zaken over de Kip van Morgen, in juni 2015. Zie verder o.a. het verslag van een Algemeen Overleg van 5 augustus 2015, over de Versterking van de positie van de consument: Kamerstukken // 2014/15, 27879, 53

22. Nu is markwerking, als efficiënt verdelingsmechanisme, op geaggregeerd niveau natuurlijk ook in het publiek belang.

23. Zie o.a. over de achterliggende waarden van mededinging en van duurzaamheid: A. Gerbrandy, 'Competition Law and Private-Sector Sustainability Initiatives. Government Action or Private Initiatives in Reaction to Science's Call for Sustainability', in: A.L.B. Colombi Ciacchi, M.A. Heldeweg, B.M.J. van der Meulen en A.R. Neerhof (red.), Law \& governance. Beyond the public-private law divide?, Den Haag: Eleven International Publishing 2013, p. 81-104.

24. Zie over 'fairness' in het mededingingsrecht bijvoorbeeld T.J. Horton, 'Fairness and Antitrust Reconsidered: An Evolutionary Perspective', McGeorge Law Review (44) 2013, afl. 4, p. 823-863; E.D. Hughes, 'The Left Side of Antitrust: What Fairness Means and Why it Matters', Marquette Law Review (77) 1994, afl. 2, p. 265-306; D.J. Gerber, Fairness in Competition Law: European and U.S. Experience (Conference on Fairness and Asian Competition Laws 5 maart 2004), Kyoto 2004, $<$ Archive.kyotogakuen.ac.jp/o_ied/information/fairness_in_ competition_law.pdf>; G. Amato, Antitrust and the Bounds of Power. The dilemma of liberal democracy in the history of the market, Oxford: Hart Publishing 1997; C. Ahlborn en A.J. Padilla, 'From Fairness to Welfare', in: C.D. Ehlerman en M. Marquis (red.), European Competition Law Annual 2007, Oxford: Hart Publishing 2008; M.E. Stucke, 'Should Competition Policy Promote Happiness?', Fordham Law Review (81) 2013, afl. 5, p. 2575-2644.

25. Zie voor een introductie: <tippingpointplanner.org/resources/whitepapers/176-tipping-points-explained>.

26. Zie voor een algemene discussie van dit punt, gebaseerd op de richtsnoeren art. 101 lid 3 VWEU van de Commissie, bijvoorbeeld R. Whish en D. Bailey, Competition Law, Oxford: Oxford University Press 2015, p. 172.

27. Zie in algemene zin M.J. Sandel, What Money Can't Buy. The Moral Limits of Markets, London: Allen Lane 2012.
De vraag naar de verhouding tussen economische en niet-economische belangen in het mededingingsrecht is geen nieuwe vraag. ${ }^{28}$ Zoals de filosoof Prediker al zei: 'Er is niets nieuws onder de zon'. ${ }^{29}$ Mijn Leidse collega Tom Ottervanger, bijvoorbeeld, besteedde zijn oratie aan hetzelfde thema. ${ }^{30}$ Maar vanwege de veranderende maatschappelijke context moet het antwoord opnieuw worden onderzocht: de noodzaak tot verduurzaming van de economie vraagt om herbezinning van de juridische fundamenten onder de economische ordening en op de vraag of het mededingingsrecht niet te eng economisch is geworden en of het niet ook rechtvaardige uitkomsten dient na te streven. Het groeiend besef van het belang van maatschappelijk verantwoord ondernemen, zowel op lokaal als op mondiaal niveau, vraagt om een beschouwing over de rol van ondernemingen in deze economische ordening. En de veranderde verhouding tussen markt en overheid en maatschappelijk midden, opnieuw op nationaal, Europees en mondiaal niveau, is aanleiding om de legitimiteit van de definiëring van wat onder het 'publiek belang' wordt verstaan opnieuw te onderzoeken.

Hoewel de grutto een niet heel opvallende vogel is (een skier proleetsje zou in navolging van Fedde Schurer kun-

28. Zie, onder andere (!): T. Prosser, The Limits of Competition Law. Markets and Public Services, Oxford: Oxford University Press 2005; D. Zimmer (red.), The Goals of Competition Law, Cheltenham: Edward Elgar 2012; O. Budzinski, 'Monoculture versus Diversity in Competition Economics', Cambridge Journal of Economics (32) 2008, afl. 2, p. 295-324; C. Townley, 'Is Anything More Important than Consumer Welfare (in Article 81 ERC)? Reflections of a Community Lawyer', Cambridge Yearbook of European Legal Studies (10) 2008, p. 345-381; C. Townley, Article 81 EC and Public Policy, Oxford: Hart Publishing 2009; A. Gerbrandy, 'Competition Law and Private-Sector Sustainability Initiatives. Government Action or Private Initiatives in Reaction to Science's Call for Sustainability', in: A.L.B. Colombi Ciacchi, M.A. Heldeweg, B.M.J. van der Meulen en A.R. Neerhof (red.), Law \& governance. Beyond the public-private law divide?, Den Haag: Eleven International Publishing 2013, p. 81-104; O. Odudu, The Boundaries of EC Competition Law: The Scope of Article 101, Oxford: Oxford University Press 2006; W. Kerber, 'Should Competition law Promote Efficiency? Some Reflections of an Economist on the Normative Foundations of Competition Law', in: J. Drexl, L. Idot en J. Moneger, Economic Theory and Competition Law, Cheltenham: Edward Elgar 2009; I. Lianos, 'Some reflections on the question of the goals of EU competition law', in: I. Lianos en D. Geradin (red.), Handbook In EU Competition Law: Substantive Aspects, Cheltenham: Edward Elgar 2013, p. 1-85; O. Andriychuck, 'Rediscovering the Spirit of Competition: On the Normative Value of the Competitive Process', European Competition Journal (6) 2010, afl. 3, p. 575-610; O. Black, Conceptual Foundations of Antitrust, Cambridge: Cambridge University Press 2005.

29. Prediker 1:9.

30. T.R. Ottervanger, Maatschappelijk verantwoord concurreren: mededingingsrecht in een veranderende wereld (oratie Leiden), 19 maart 2010. Als een van de kernvragen van het Economisch Publiekrecht wordt beschouwd de verhouding tussen de economische grondslag van dit recht en de normatieve basis daarvan in de rechtsbeginselen van vrijheid, gelijkheid en solidariteit. Zie K. Hellingman en K.J.M. Mortelmans, Economisch Publiekrecht: rechtswaarborgen en rechtsinstrumenten, Deventer: Kluwer 1989. Ook Johan van de Gronden en Saskia Lavrijssen, beiden uit de Utrechtse school, hebben zich met deze vraag beziggehouden: J.W. van de Gronden en K.J.M. Mortelmans, Mededinging en niet-economische belangen, Deventer: Kluwer 2001; S.A.C.M. Lavrijssen, 'The protection of non-competition interests: What role for competition authorities after Lisbon', European Law Review 2010, afl. 5, p. 634-659. 
nen worden gezegd) ${ }^{31}$ staat hij symbool voor grote vragen.

\section{Overheid, markt en 'civil society' in het mededingings- recht}

De centrale stelling van mijn betoog is dat het mededingingsrecht moet veranderen, om ook in de toekomst zijn relevantie - en daarmee legitimiteit - te behouden. In het mededingingsrechtelijk landschap is de Europese Commissie een belangrijke instelling; men zou kunnen stellen dat het mededingingsrecht, om te beginnen, dus daar zou moeten veranderen. Maar het is uiteindelijk niet de Europese Commissie die over de betekenis van het mededingingsrecht het laatste woord heeft; dat ligt bij het Europees Hof van Justitie in Luxemburg. Het Hof van Justitie heeft geoordeeld dat consumentenwelvaart een van de doelstellingen van mededingingsrecht is, maar niet de enige doelstelling. ${ }^{32}$ Het Hof van Justitie hangt aan waardenpluralisme, wat logisch is gezien de Europese materieelrechtelijke constitutionele context. ${ }^{33}$ De Europese Unie is gegrond in een socialemarkteconomie, én is gebaseerd op de waarde van duurzaamheid, én op bescherming van het milieu. Ook voor het mededingingsrecht betekent dit dat er geen a priori rangschikking bestaat tussen het economische en het niet-economische belang. ${ }^{34}$

Dat laatste geldt ook voor een ander belangrijk onderdeel van het internemarktrecht, namelijk het vrijverkeerrecht, waarmee het mededingingsrecht van oudsher nauw verbonden is. ${ }^{35}$ Een belemmering van de goede werking van het vrij verkeer binnen de Europese interne markt (het marktbelang) kan onder voorwaarde van proportionaliteit zijn toegestaan ter bescherming van niet-

31. Naar een gedicht van Fedde Schurer, 'Wille': ‘De mosk yn de moudige reedsjes - is gjin dei fan syn fretten wis. Mar net ien fan dy skiere proleetsjes - dy't by God fergetten is'.

32. Vgl. HvJ EG 4 juni 2009, zaak C-8/08, T-Mobile Nederland e.a./NMa, ECLI:EU:C:2009:343.

33. Zie art. 2 en 3 VEU en de integratiebepalingen, waaronder art. 11 VWEU. Zie ook: M. Scholten en A. Gerbrandy, 'Core values: tensions and balances in the EU shared legal order', in: T. van den Brink, M. Luchtman en M. Scholten (red.), Sovereignty in the shared legal order of the EU. Core values of Regulation and Enforcement, Maastricht: Intersentia 2015, p. 9-30. Over de integratiebepaling van art. 11 VWEU: S. Kingston, Greening EU Competition Law and Policy, Cambridge: Cambridge University Press 2012. Over de economische constitutie en de rol van niet-economische belangen daarin ook: D. Gerber, 'Constitutionalizing the Economy: German Neo-liberalism, Competition Law and the "New" Europe', American Journal of Comparative Law (42) 1994, afl. 1, p. 25-84; D. Gerber, Law and competition in Twentieth Century Europe, Oxford: Clarendon Press 1998.

34. Protocol 27 brengt in deze niet-hiërarchische ordening geen verandering, ook niet voor het mededingingsrecht: G. Monti, 'EU competition law from Rome to Lisbon. Social market economy', in: C. Heide-Jørgensen, C. Bergqvist, U.B. Neergard en S. Troels Poulsen (red.), Aims and values in competition law, Kopenhagen: DJØF Publishing 2013, p. 27-66.

35. Over deze verbinding o.a. HvJ EG 13 juli 1966, zaak C-56/64, Consten en Grundig/Commissie van de EEG, ECLI:EU:C:1966:41. economische belangen, zoals gezondheid, milieubescherming en sociale belangen. Nu gaat het in het vrijverkeerrecht over het algemeen om belemmeringen die door de lidstaten zelf worden veroorzaakt: zowel de verbodsbepalingen als de uitzonderingsbepalingen liggen in het publiek domein. Dat is een verschil met het mededingingsrecht, waar ondernemingen nu een beroep doen op uitzonderingen die zien op dit type belangen, die van oudsher worden beschermd in het publiek domein. Maar het is een ondergeschikt verschil: zoals onder andere mijn collega Sybe de Vries heeft laten zien brengt de horizontale werking van de vrijverkeerbepalingen mee dat ook niet-publieke partijen een beroep kunnen doen op de uitzonderingen. ${ }^{36}$ Daarmee is er sprake van een vervaging tussen de grenzen van de verboden en uitzonderingen die zijn gericht tot de lidstaten, en de verboden en uitzonderingen gericht tot ondernemingen.

Die vervaging in het internemarktrecht past in de hiervoor genoemde bredere maatschappelijke ontwikkeling, waarin een vervaging aan de orde is van de grenzen tussen het publiek domein en het marktdomein. De introductie van liberalisering, privatisering en marktwerking betekende een groeiende invloed van de economische rationaliteit (of zij was daar het gevolg van), en een versterking van het marktdomein. Dat is het domein van producenten en consumenten. Ook de behartiging van wat voorheen publieke taken waren, in overheidshanden, is voor een groter deel aan de markt overgedragen. En ondernemingen, in dat marktdomein, trekken zich vanwege maatschappelijk verantwoord ondernemen het publiek belang aan. De markt heeft aan invloed gewonnen en het publiek domein - het domein van overheid en burger - heeft aan invloed verloren. ${ }^{37}$

$\mathrm{Nu}$ heeft het mededingingsrecht op zich altijd wel oog gehad voor de relatie tussen de markt en de overheid. Er is bijvoorbeeld een specifieke regel gericht op ondernemingen die door de overheid zijn belast met het aanbieden van diensten van algemeen economisch belang (art. $106 \mathrm{VWEU).} \mathrm{Maar} \mathrm{dat} \mathrm{is} \mathrm{een} \mathrm{regeling} \mathrm{die} \mathrm{past} \mathrm{bij}$ een klassieke rolverdeling: de overheid is er voor de waarborging van het publiek belang, ondernemingen niet, tenzij zij door de overheid daartoe een specifieke taak krijgen toebedeeld. Die klassieke rolverdeling is nu juist door de verandering in de verhouding tussen markt en overheid aan het verschuiven. En dat betekent dat de behartiging van het publiek belang niet meer in het

36. Zie o.a. C. Krenn, "A missing piece in the horizontal effect "jigsaw": Horizontal direct effect and the free movement of goods', Common Market Law Review (49) 2012, afl. 1, p. 177-216. Over horizontale werking van de vrijverkeerbepalingen ook: S.A. de Vries en R. van Mastrigt, 'Horizontal direct effect of the Four Freedoms. From a hodgepodge of cases to a seamless web of judicial protection in the EU Single Market?', in: U. Bernitz, X. Groussot en F. Schulyok (red.), General Principles of EU Law and European Private Law, Deventer: Kluwer 2013, p. 249-280. Over de link tussen vrij verkeer en mededingingsrecht ook: K.J.M. Mortelmans, 'Towards Convergence in the Application of the Rules on Free Movement and on Competition?', Common Market Law Review (38) 2001, afl. 3, p. 613-649; S.A. de Vries en A. Gerbrandy, 'Convergentie tussen vrij verkeer en mededinging "revisited"', SEW 2015, afl. 11, p. 516-521.

37. Zie literatuur genoemd in voetnoten hiervoor. 
exclusieve domein van de overheid ligt. Het mededingingsrecht moet hierop een antwoord formuleren. Ik licht twee elementen uit deze ontwikkeling die bij dat antwoord formuleren behulpzaam kunnen zijn: de rol van de civil society en de rol van ondernemingen zelf.

Over het algemeen is er in het mededingingsrechtelijk denken, op uitzonderingen na, weinig aandacht voor de rol van het maatschappelijk midden. ${ }^{38}$ Terwijl het maatschappelijk midden - de civil society - belangrijk is in de definiëring van de inhoud van wat het publiek belang is, en een legitimerende rol kan spelen in het proces waarin dat wordt bepaald. ${ }^{39}$ Dat maatschappelijk midden bestaat bijvoorbeeld uit de vakbeweging en uit non-profitinstellingen met ideële doelstellingen, maar ook uit andere vormen van activistische groeperingen, zoals groepen die vooral actief zijn op sociale media. Deze instituties gezamenlijk zijn in organisatorische zin de civil society: zij maken deel uit van de ruimte tussen de overheid en de markt waar, min of meer georganiseerd, met elkaar invulling wordt gegeven aan wat een 'goede' samenleving is. ${ }^{40} \mathrm{Net}$ als dat sommige belangen zich onttrekken aan landsgrenzen zijn ook sommige groepen grensoverschrijdend: zij maken deel uit van een 'global civil society'. Op dit bovenstatelijk niveau, waar een overheid ontbreekt, is overleg met en tussen de organisaties van het maatschappelijk midden een belangrijke manier om invulling te kunnen geven aan de inhoud van grensoverstijgende publieke belangen. ${ }^{41}$ Dat betekent natuurlijk niet dat de invulling van 'het goede' daarmee vaststaat. Voor zover dat theoretisch gezien al mogelijk zou kunnen zijn in onze postmoderne tijd is er ook in praktische zin sprake van een ideeënstrijd tussen organisaties. Het is ook niet direct duidelijk dat het maatschappelijk midden (gezamenlijk) spreekt voor een algemeen of een gedeeld publiek belang, of er deelbelangen zijn die niet gerepresenteerd zijn, en of de instanties wel zélf democratisch gelegitimeerd zijn (of moeten zijn). ${ }^{42}$ Bij een invulling van de rol van het maatschappelijk midden in het mededingingsrechtelijk dilemma van deze oratie, zijn dat belangrijke kanttekeningen.

Het past vervolgens ook in de verschuiving tussen publiek en privaat domein dat van ondernemingen (mede onder druk van de civil society) méér wordt verwacht dan alleen het nastreven van het eigen belang. Van ondernemingen wordt responsible business conduct

38. Wel (o.a.): J.W. van de Gronden, 'EG-recht en het maatschappelijk middenveld', SEW 2001, afl. 9, p. 302-313.

39. 'Maatschappelijk midden(veld)' en 'civil society' hebben niet helemaal dezelfde lading. Mijn indruk is dat het begrip maatschappelijk midden beperkter is dan het begrip civil society. Misschien is het begrip 'maatschappelijke organisaties' beter, maar dat mist weer de metaforische betekenis van het begrip civil society.

40. Zie over het concept civil society: M. Edwards, Civil Society, Cambridge: Polity Press 2014.

41. M. Kaldor, 'The idea of global civil society', International Affairs (79) 2003, afl. 3, p. 283-593; M. Castells, 'The New Public Sphere: Global Civil Society, Communication Networks, and Global Governance', ANNALS of the American Academy of Political and Social Science 2008, afl. 616, p. 78-93.

42. A.M. Eikenberry en J.D. Klover, 'The Marketization of the Nonprofit Sector: Civil Society at Risk?', Public Administration (64) 2004, afl. 2, p. $132-140$. verwacht, ook op mondiaal niveau. ${ }^{43}$ Dat betekent dat ondernemingen zich de impact moeten aantrekken van hun handelen op de maatschappij, inclusief het milieu: zij moeten negatieve impact voorkomen, verminderen en zo mogelijk herstellen. Het gevolg van deze beweging is dat marktpartijen méér verantwoordelijkheid krijgen, met een ander accent dan alleen het winstbelang van de onderneming zelf. Vanuit een normatief oogpunt betekent dit dat op ondernemingen, onafhankelijk van de overheid, een eigen ethische verplichting rust om zich hun invloed op het publiek belang aan te trekken. ${ }^{44} \mathrm{Dit}$ kan ondernemingsrechtelijke en aansprakelijkheidsrechtelijke gevolgen hebben, zoals mijn collega's bij het Molengraaff Instituut onderzoeken. ${ }^{45}$ Maar het verandert ook de legitimiteit van het handelen van ondernemingen, ook als zij dat gezamenlijk doen, ${ }^{46}$ en dus is het de vraag of de veranderde normatieve basis van dergelijke afspraken ook in het mededingingsrecht een plaats moet krijgen.

$\mathrm{Nu}$ kan het zijn dat $\mathrm{u}$ de volgende afwerende reactie heeft: 'Ja, maar Anna, in plaats van dit allemaal een plaats te geven, ook in het mededingingsrecht, zoals jij lijkt te gaan willen doen, moeten ondernemingen zich het publiek belang helemaal niet willen aantrekken. De overheid moet publieke belangen waarborgen, liefst door democratisch gelegitimeerde wetgeving.' Een variant van deze algemene reactie is te zien in het huidige debat over het mededingingsrecht: het mededingingsrecht moet zich niet buigen over publieke belangen. Het

43. Responsible business conduct en corporate social responsibility lijken elkaar grotendeels overlappende concepten. Zie over RBC: OECD Guidelines for Multinational Enterprises, Paris: OECD 2012; voor de EU: Mededeling van de Commissie aan het Europees Parlement, de Raad, het Europees Economisch en Sociaal Comité en het Comité van de Regio's. Een vernieuwde EU-Strategie 2011-2014 ter bevordering van maatschappelijk verantwoord ondernemen, COM/2011/0681 def.; voor de VN: United Nations Global Compact, UN 2000, $<$ Unglobalcompact.org> (zoek op Global Compact 2000).

44. Er zijn natuurlijk velerlei redenen voor ondernemingen om maatschappelijk verantwoord te ondernemen, maar dat verandert de ethische verplichting om dat te doen niet. Zie over de verschillende redenen o.a.: J. Graafland, M. Kaptein en C. Mazereeuw, Motives for Socially Responsible Business Conduct (Tilburg University CentER Discussion Paper Series 2010-74), <Ssrn.com> (zoek op Graafland Responsible Business Conduct); D. Baron, 'Morally Motivated Self-Regulation', American Economic Review (100) 2010, afl. 4, p. 1299-1329; D. Vogel, 'The Private Regulation of Global Corporate Conduct', Business \& Society (49) 2010, afl. 1, p. 68-87

45. Zie bijvoorbeeld L. Enneking, Foreign direct liability and beyond. Explor ing the role of tort law in promoting international corporate social responsibility and accountability (diss. Utrecht), Den Haag: Eleven International Publishing 2012; L. Enneking, F. Kristen, K. Pijl, T. Waterbolk, J. Emaus, M. Hiel, A. Schaap en I. Giesen, Zorgplichten van Nederlandse Ondernemingen inzake Internationaal Maatschappelijk Verantwoord Ondernemen. Een rechtsvergelijkend en empirisch onderzoek naar de stand van het Nederlandse recht in het licht van de UN Guiding Principles (UCALL rapport december 2015), Den Haag: WODC 2015, $<$ Rijksoverheid.nl> (zoek op Zorgplichten maatschappelijk verantwoord ondernemen).

46. Zie over het fenomeen 'transnational private regulation' - het 'gezamenlijk doen' - maar dan zonder een mededingingsrechtelijke invalshoek o.a.: F. Cafaggi, 'New Foundations of Transnational Private Regulation', Journal of Law and Society (38) 2011, afl. 1, p. 20-49; J. Gond, $\mathrm{N}$. Kang en J. Moon, 'The government of self-regulation. On the comparative dynamics of corporate social responsibility', Economy and Society (40) 2011, afl. 4, p. 640-671. 
mededingingsrecht dient gericht te blijven op marktefficiëntie (en consumentenwelvaart), en noties als 'fairness' hebben daarin geen plaats. Dat wél toestaan leidt tot politieke en subjectieve besluitvorming (wat soms als synoniem van elkaar wordt gebruikt). Als het publiek belang niet via het politieke proces kan worden behartigd dan is er niet alsnog een rol voor ondernemingen om zich dat aan te trekken. Al helemaal niet als ze daarmee het mededingingsrecht overtreden: dat is het verschaffen van een public interest veil voor kartels en een dekmantel voor greenmashing daarvan. ${ }^{47}$

Mij lijkt dit een onhoudbare reactie. In het licht van de geschetste maatschappelijke ontwikkelingen is het als een spook terugduwen in een hok. Zelfs mijn jongste zoon weet dat dat onmogelijk is. Maar, belangrijker, het is normatief onhoudbaar. Die stelling is allereerst gebaseerd op de noodzaak van een duurzame maatschappij. Die noodzaak brengt een normatieve verplichting mee, zowel in individueel-ethische zin, maar ook - afgeleid uit de Europese constitutionele inbedding van dit recht - in juridische zin. De normatieve onhoudbaarheid is ten tweede gebaseerd op het hiervoor genoemde fundamentele heroverwegen van de eigen legitimiteit van gezamenlijk ondernemingshandelen in het publiek belang.

Dat laatste vergt wellicht enige nadere toelichting. Immers, over het algemeen is de noodzaak van legitimiteit verbonden aan dwingende handelingen van de overheid. Inperking van de handelingsvrijheid van burgers behoeft legitimiteit. $\mathrm{Nu}$ is legitimiteit een gelaagd begrip maar in de kern is het in normatieve zin de kwalitatieve basis waarop overheidsgezag rust. ${ }^{48}$ In algemene zin verkrijgt het handelen van de overheid in het publiek belang legitimiteit via de democratische inrichting van de maatschappij, waarbij de burger en de civil society als sfeer tussen burger en overheid betrokken zijn. Legiti-

47. Vanuit de Nederlandse context o.a. E. Loozen, 'De onwenselijkheid van de beleidsregel mededinging en duurzaamheid', ESB 2015, p. 746-750; P. de Bijl en T. van Dijk, 'Mededingingsbeleid en publieke belangen: een economisch perspectief', M\&M 2012/4, p. 149-156; M.P. Schinkel en Y. Spiegel, Can Collusion Promote Sustainable Consumption and Production? (Amsterdam Centre for Law and Economics Working Paper 2015-02), Amsterdam 2015, <Ssrn.com> (zoek op 2704259); B. Baarsma, 'Rewriting European Competition Law from an Economic Perspective', European Competition Journal 2011, afl. 3, p. 559-585.

48. Zie (o.a. en als topje van een ijsberg): J. Rawls, Political Liberalism, New York: Columbia University Press 1993, maar zie ook voor een introductie: Stanford Encyclopedia of Philosophy, <Plato.stanford.edu> (zoek op political legitimacy); en verder J. Habermas, Between Facts and Norms. Contributions to a discourse theory of law and democracy, Cambridge, MA: MIT Press 1996; C. Matheson, 'Weber and the Classification of Forms of Legitimacy', British Journal of Sociology (38) 1987, afl. 2, p. 199-215; A. Buchanan, 'Political Legitimacy and Democracy', Ethics (112) 2002, afl. 4, p. 689-719; S. Chambers, 'Deliberative Democratic Theory', Annual Review of Political Science (6) 2003, afl. 1, p. 307-326; V. Schmidt, 'Democracy and Legitimacy in the European Union Revisited. Input, Output and "Throughput"', Political Studies (61) 2013, afl. 1, p. 2-22; J. Parkinson, 'Legitimacy Problems in Deliberative Democracy', Political Studies (51) 2003, afl. 1, p. 182; over legitimiteit van besluitvorming door ACM in besluiten waarin niet-economische belangen aan de orde zijn ook: A. Gerbrandy, 'Addressing the Legitimacy Problem for Competition Authorities Taking into Account Non-Economic Values: The Position of the Dutch Competition Authority', European Law Review (40) 2015, afl. 5, p. 769-781. miteit van ondernemingshandelen dat het eigen (winst)belang behartigt, is in deze zin geen issue. Maar heroverweging van de rol van ondernemingen in het publiek belang betekent ook heroverweging van het legitimiteitsbegrip. Rutger Claassen en ik betogen elders dat samenwerking tussen ondernemingen gericht op het behartigen van een publiek belang legitimiteit niet alleen nodig heeft, maar ook kan verkrijgen. Dat kan uiteindelijk niet helemaal zonder inmenging vanuit het publiek domein: er moet op zijn minst een mogelijkheid zijn van publiek toezicht. ${ }^{49}$ Aan die gedachtegang kan worden toegevoegd dat legitimiteit ook verkregen zou kunnen worden als het publiek belang door de civil society wordt gedragen en mede door dat maatschappelijk midden is vormgegeven.

\section{Hoe dan?}

Hiervoor stelde ik aan de orde dat het mededingingsrecht zich moet verhouden tot de veranderde samenleving, en ik schetste enkele van de voor het mededingingsrecht relevante veranderingen. Alleen op die manier behoudt dit rechtsgebied zijn eigen legitimiteit. Het is dan natuurlijk de vraag: hoe dan? Hoe kan dat juridisch vormgegeven worden, liefst zonder dat daartoe een Verdragswijziging noodzakelijk is? Ik herinner eraan dat ACM een 'nee' voor de Kip en het Energieakkoord baseerde op een beoordeling op basis van de uitzondering van artikel 101 lid $3 \mathrm{VWEU} /$ artikel 6 lid 3 Mw (zie hierboven). De discussie die daarop volgde, leidde er toe dat de minister van Economische Zaken vervolgens bezig ging, en nog is, met het opstellen van een nieuwe Beleidsregel Duurzaamheid en Mededinging. ${ }^{50}$ Deze reactie van de minister is in zekere zin een reactie op het gebrek aan maatschappelijke en politieke acceptatie van de oordelen van de toezichthouder. Daarmee kan het ook gezien worden als een reactie op het gebrek aan legitimiteit van de uitkomsten van de rechtstoepassing, in de zin dat de gezamenlijkheid van uitkomsten wel moet blijven resoneren met de waardenbeleving in de maatschappij. ${ }^{51}$ De minister is, naar het zich doet aanzien, voornemens met de Beleidsregel ACM op te dragen om duurzaamheidsverbeteringen te betrekken in haar oordelen door de uitzonderingsvoorwaarden ruimer uit te leggen dan nu het geval is. Dat ruimer uitleggen van de voorwaarden van artikel 6 lid $3 \mathrm{Mw}$ (de minister gaat niet over de uitleg van artikel 101 lid 3 VWEU, maar de scheiding tussen beide is natuurlijk lastig) is een optie; ${ }^{52}$

49. R. Claassen en A. Gerbrandy, 'Doing Good Together', 2016 (nog te verschijnen)

50. Zie Consultatieversie Beleidsregel mededinging en duurzaamheid (Beleidsnota 23 december 2015), minister van Economische Zaken 2015, <Internetconsultatie.nl/mededingingenduurzaamheid>.

51. Output-legitimiteit, zie: V.A. Schmidt, 'Democracy and Legitimacy in the European Union Revisited', Political Studies (61) 2013, afl. 1, p. 5.

52. Zie A. Gerbrandy, 'The Netherlands move ahead with Competition and Sustainability', RENFORCE Blog 2016, <Blog.renforce.eu> (zoek op Gerbrandy). 
de voor- en nadelen daarvan zijn in ieder geval tijdens de consultatie uitgebreid besproken. ${ }^{53}$

Ik wil hier daarom een van de mogelijke andere opties aan bod laten komen: een die ligt in het verlengde van bovenstaande uiteenzettingen. Daarbij sluit ik aan bij de jurisprudentie van het Hof van Justitie, waarin het Hof van Justitie bepaalt dat het mededingingsrecht op sommige typen overeenkomsten niet van toepassing is. ${ }^{54}$ Dat is een conclusie die voorafgaat aan een beoordeling onder het eerste lid van artikel 101 VWEU: aan een beoordeling van de mededingingsrechtelijke effecten wordt dan niet toegekomen. ${ }^{55}$ Het belang dat hier aan de orde is, is het sociaal belang van cao's en de dialoog die aan de totstandkoming daarvan ten grondslag ligt. Dat belang wordt belangrijker geacht dan het mededingingsbelang dat met cao-afspraken óók geraakt wordt. Het Hof van Justitie heeft in een andere, maar verwante, serie uitspraken ook geaccepteerd dat het mededingingsrecht op bepaalde entiteiten niet van toepassing is. ${ }^{56}$ Opnieuw: dat is een beoordeling die voorafgaat aan een beoordeling onder het eerste lid. Hierbij gaat het om organisaties die activiteiten uitoefenen van zuiver sociale aard en op grondslag van solidariteit. De bekende voorbeelden zijn casusspecifiek, maar ten gronde wordt steeds een afweging gemaakt tussen het mededingingsbelang en het op solidariteit gegronde publieke belang. ${ }^{57}$ Als dat laatste zo zwaar weegt dat het mededingingsrecht daar beter niet op kan worden toegepast dan wordt dat uitgesloten.

De kern van deze jurisprudentie lijkt te liggen in het begrip solidariteit. ${ }^{58}$ Dat is hier relevant, omdat ook de kern van duurzaamheidsinitiatieven ligt in solidariteit. ${ }^{59}$ Het gaat daarbij om solidariteit tussen groepen mensen, tussen generaties, en zelfs tussen mens en omgeving (hoewel dat meer omstreden is). ${ }^{60}$ Ook het begrip 'soli-

53. De consultatie is gesloten op 31 januari 2016. Zie de reacties: <internetconsultatie.nl/mededingingenduurzaamheid/reacties>.

54. Zie HvJ EG 21 september 1999, zaak C-67/96, Albany, ECLI:EU:C: 1999:430.

55. In de mededingingswet is dit gecodificeerd in art. $16 \mathrm{Mw}$

56. $E r$ is dan geen sprake van een economische activiteit, en dus geen onderneming. Zie over dit begrip ook: V. Hatzopoulos, The concept of 'economic activity' in the EU Treaty: from ideological dead-ends to workable judicial concepts (College of Europe Research Paper in Law 06/2011), Brugge 2011.

57. Zie o.a. HvJ EG 17 februari 1993, zaak C-159/91, Poucet, ECLI:EU:C: 1993:63; HvJ EG 16 november 1995, zaak C-244/94, FFSA, ECLI:EU:C: 1995:392; HvJ EG 16 maart 2004, zaak C-264/01, AOK, ECLI:EU:C: 2004:150.

58. Zie ook: N. Boeger, 'Solidarity and EC Competition Law', European Law Review (32) 2007, afl. 3, p. 319-340; A. Winterstein, 'Nailing the Jellyfish: Social Security and Competition Law', European Competition Law Review (20) 1999, afl. 6, p. 324-333.

59. Zie ook A. Gerbrandy, 'Competition Law and Private-Sector Sustainability Initiatives. Government Action or Private Initiatives in Reaction to Science's Call for Sustainability', in: A.L.B. Colombi Ciacchi, M.A. Heldeweg, B.M.J. van der Meulen en A.R. Neerhof (red.), Law \& governance. Beyond the public-private law divide?, Den Haag: Eleven International Publishing 2013, p. 81-104, met name tekst behorend bij voetnoten 44-60.

60. R. Claassen en A. Gerbrandy, 'Rethinking European Competition Law. From a Consumer Welfare to a Capability Approach', Utrecht Law Review (12) 2016, afl. 1, p. 13. dariteit' is natuurlijk gelaagd. ${ }^{61}$ Het gaat in ieder geval om een begrip dat de relaties tussen groep en individu betreft en dat morele wederzijdse verplichtingen omvat. Gebaseerd op het klassiek-liberale idee dat aan eenieder gelijke rechten toekomen, kent solidariteit in normatieve zin geen grenzen, in die zin dat de ander immers inherent en fundamenteel gelijk is. Maar dat hoeft niet te kloppen met de maatschappelijke werkelijkheid en sociale solidariteit: er zijn wel degelijk grenzen aan onze solidariteit, die met name samenhangen met de cultureel-historische bepaaldheid van identiteit. ${ }^{62}$ Dat kan ook normatief gegrond worden, bijvoorbeeld als solidariteit wordt verbonden aan 'community', zoals dat ten grondslag ligt aan sociaalrechtelijke jurisprudentie van het Hof van Justitie. ${ }^{63}$

Solidariteit ten grondslag leggen aan het uitsluiten van mededingingsrecht op duurzaamheidsinitiatieven betekent ten gronde een zoektocht naar een rechtvaardigheidstheorie die aan het mededingingsrecht (of in ieder geval deze uitsluiting) ten grondslag wordt gelegd. Rutger Claassen en ik hebben daarover, ook in relatie tot het vraagstuk van niet-economische belangen in het mededingingsrecht, wel eerste gedachten gepubliceerd; ${ }^{64}$ het gaat te ver om deze zoektocht naar rechtvaardigheidstheorie hier helemaal te voltooien. Ik beperk mij voor nu daarom tot twee overpeinzingen.

Neem (ten eerste) geografische grenzen. Hier is de kernvraag of een hoger loon voor het werk van de Indiase arbeidster, te betalen door de (over het algemeen welvarende) T-shirt-kopende consument in de Europese Unie, in normatieve zin in het mededingingsrecht een plaats moet krijgen. Als we vinden dat het al dan niet toestaan van een dergelijke mededingingsbeperkende afspraak niet moet afhangen van de vraag hoeveel de consument bereid is daarvoor te betalen - want de markt is een te smalle normatieve basis ${ }^{65}$ - dan is het de vraag op welke normatieve basis een dergelijke afweging dan wel kan worden gemaakt. Het is de klassieke notie van solidariteit die hier dan een normatieve grond biedt voor het buiten toepassing laten van het mededingingsrecht. Maar neem (ten tweede) nu solidariteit met de grutto. Er zijn goede filosofische gronden voor solidariteit met

61. Door A-G Fennelly als volgt omschreven: 'Bij sociale solidariteit gaat het om onvrijwillige subsidiëring van de ene sociale groepering door de andere, een van nature niet-commerciële handelwijze' (A-G Fennelly, ECLI:EU:C:1997:55, punt 29). Deze definitie lijkt af te wijken van hoe in politieke filosofie solidariteit wordt begrepen.

62. Zie in algemene zin ook: J. Habermas, Between Facts and Norms. Contributions to a discourse theory of law and democracy, Cambridge, MA: MIT Press 1996.

63. M. Dougan en E. Spaventa, “"Wish You Weren't Here...", New Models of Social Solidarity in the European Union', in: M. Dougan en E. Spaventa (red.), Social Welfare and EU Law, Oxford: Hart Publishing 2005, p. 181-218.

64. R. Claassen en A. Gerbrandy, 'Rethinking European Competition Law. From a Consumer Welfare to a Capability Approach', Utrecht Law Review (12) 2016, afl. 1, p. 1-15.

65. Dat wil niet zeggen dat het marktmechanisme, of de grondslagen waarop het rust, zelf geen normatieve lading kan hebben, zie o.a. B. Amable, 'Morals and politics in the ideology of neo-liberalism', Socio-Economic Review (9) 2010, afl. 1, p. 3-30. 
dieren (non-human animals tenslotte), ${ }^{66}$ maar toch aarzel ik: we zijn misschien wel begaan met de grutto maar dat betekent niet dat we die als gelijke beschouwen. De kern van solidariteit ligt hier anders: de grutto - die hier als stand-in wordt gebruikt voor veel milieubeschermingsmaatregelen - wordt beschermd als onderdeel van bescherming van het ecosysteem als geheel en is dan uitdrukking van solidariteit tussen generaties. ${ }^{67}$ Maar daarmee komen wel grenzen van solidariteit in de tijd in zicht. ${ }^{68}$ Misschien kan solidariteit hier ook worden opgevat als een morele verplichting die zijn grondslag vindt in het idee van 'ecological stemardship'. ${ }^{69}$ Dat zal bij sommigen van $\mathrm{u}$ als het rentmeesterschap uit de christelijke traditie bekend zijn, maar ook los van theologie kan hierin een normatieve basis liggen voor duurzaamheidsinitiatieven gericht op behoud voor toekomstige generaties.

Naast wat juridisch-technische fijnslijperij ${ }^{70}$ is er nog een punt om op te lossen voordat deze solidariteitsroute bij duurzaamheidsinitiatieven kan worden gebruikt. Er is in de zaken van het Hof van Justitie namelijk wel steeds sprake van vormgeving en inmenging door de overheid van de op solidariteitsgrondslag georganiseerde activiteiten. Alleen dán is het mededingingsrecht niet van toepassing. Maar ook deze voorwaarde moet worden herbezien in het licht van de veranderde verhouding tussen publiek en privaat, tussen overheid en markt. Immers, inmenging van de overheid is een logische voorwaarde in een klassieke taakverdeling tussen markt en overheid. Dit verschaft legitimiteit aan het ondernemershandelen dat een publiek belang nastreeft. Dat brengt mij terug bij wat ik hiervoor over de rol van civil society en ondernemingen zélf heb betoogd: die legitimiteit kan ook worden verkregen doordat het maatschappelijk midden een rol heeft in het definiëren van het publiek belang; of - gebaseerd op de zelfstandige ethische verplichtingen van ondernemingen - die definiëring wordt helemaal overgelaten aan ondernemingen,

66. Dat betekent dat zij ook rechten hebben, zie bijvoorbeeld M.C. Nussbaum, Frontiers of Justice, Cambridge, MA: Harvard University Press 2006.

67. Zie hierover, opnieuw als basistekst: G.H. Brundtland, Our Common Future: The World Commission on Environment and Development, New York: Oxford University Press 1987.

68. Bijvoorbeeld P.M. Martens, 'Sustainability: science or fiction?', Sustainability: Science, Practice \& Policy 2006, afl. 1, p. 36-41; zie ook R.B. Norgaard en R.B. Howarth, 'Sustuabinability and discounting the future', in: Ecological Economics: The Science and Management of Sustainability, p. 88-101.

69. Bijvoorbeeld bij R. Scruton, Green philosophy. How to think seriously about the planet?, Londen: Atlantic Books 2012.

70. Bijvoorbeeld: het Hof van Justitie heeft deze uitzondering vooralsnog toegepast op organisaties die alleen maar deze op solidariteitsgrondslag gebaseerde activiteit uitoefenen (dat kan wel interessant zijn voor sociaal ondernemerschap). Deze beperking in de toepassing is op te lossen door niet de organisaties, maar de activiteiten die op solidariteitsgrondslag worden uitgeoefend door deze uitzondering te vangen. Dat is juridisch niet vreemd: de nadruk op activiteiten past in feite beter bij het mededingingsrecht, dat immers ook ondernemingsactiviteiten, uitgeoefend door een overheidsorgaan van haar overheidstaken kan scheiden. onder voorwaarde van de mogelijkheid van publiek toezicht. $^{71}$

Dit laatste komt dicht in de buurt van de polderplusroute, een benaming van mijn Amsterdamse collega Rein Wesseling (die dat weer baseerde op een discussie tijdens een mededingingscongres). ${ }^{72}$ Kort gezegd wordt daarbij de zogenoemde nuttigeffectjurisprudentie omgedraaid, en gebruikt als een schild tegen mededingingsrechtelijke afkeuring. ${ }^{73}$ Voorgesteld wordt dat tussen ondernemingen overeengekomen duurzaamheidsinitiatieven door algemeenverbindendverklaring met overheidsgoedkeuring worden vastgesteld. ${ }^{74}$ Ook hier is dus de overheid in het vormgeven van het publiek belang betrokken, maar wel - en dat lijkt mij anders dan in de bestaande jurisprudentie op dit leerstuk - vooral aan het eind van het proces. ${ }^{75}$ Bovendien is hier sprake van een dunne scheidslijn tussen stimulering door de overheid van een kartelafspraak - juist verboden - en het legitiem aan een duurzaamheidsafspraak een overheidskarakter verlenen. Dat onderscheid behoeft dan verdere normatieve inkleuring, zowel wat materiële rechtvaardigingsgrond betreft, als procedureel, waarbij vooral de daadmerkelijke publiekbelangtoets belangrijk is. Ook daarvoor geldt: de rol van de civil society in het vormgeven van het publiek belang kan daarin een belangrijke factor zijn.

Het is van belang te benadrukken dat deze interpretatieroutes al bestaan; er is geen verdragswijziging voor nodig om ze toe te passen. De jurisprudentie van het Hof van Justitie is weliswaar casuïstisch, maar biedt ook ondersteuning van het argument dat de Verdragscontext ruim genoeg is voor een herinterpretatie van de verhouding tussen niet-economische belangen en mededingingsbelangen. Natuurlijk is voor een verbreding van de acceptatie van toepassing van deze routes - door bijvoorbeeld nationale toezichthouders - juridisch erken-

71. Dat komt in de buurt van, maar is conceptueel dan, het idee van corporate citizenship. Daarover o.a. A. Carroll, 'The Pyramid of Corporate Social Responsibility. Towards the Moral Management of Organizational Stakeholders', Business Horizons (34) 1991, afl. 4, p. 39-48; A. Carroll, 'The four Faces of Corporate Citizenship', Business and Society Review (100-101) 1998, afl. 1, p. 1-7; D. Windsor, 'The Future of Corporate Social Responsibility', International Journal of Organizational Analysis (9) 2001, afl. 3, p. 225-256; D. Birch, 'Corporate Citizenship Rethinking Business beyond Social Responsibility', in: J. Andriof en M. Mclntosh, Perspectives on Corporate Citizenship, Sheffield: Greenleaf 2001, p. 53-65; J. Moon, A. Crane en D. Matten 'Can Corporations be Citizens? Corporate citizenship as a Metaphor for Business Participation in Society', Business Ethic Quarterly (15) 2005, afl. 3, p. 419-453 en het gerelateerde 'global citizenship': D.J. Wood en J.M. Logsdon, 'Business Citizenship: From Individuals to Organizations', Business Ethics Quarterly (3) 2001, afl. 3 (bijzonder nummer), p. 59-94.

72. R. Wesseling, "“Polder-Plus"-model: oplossing "Kip van Morgen" ligt niet bij ACM maar bij minister', M\&M 2015/6, p. 220-221.

73. Zie o.a. HvJ EG 16 november 1977, zaak C-13/77, INNO/ATAB, ECLI:EU:C:1977:185 en HvJ EG 3 december 1987, zaak C-136/86, BNIC/Aubert, ECLI:EU:C:1987:524

74. Op die manier worden de op ondernemingen gerichte mededingingsbepalingen buiten toepassing geplaatst.

75. In bestaande jurisprudentie gaat het om casus waarin de overheid aan het begin betrokken is, in de vormgeving van de overdracht, en ook eindverantwoordelijkheid draagt. In de polderplusroute lijkt alleen dat tweede aan de orde: het initiatief blijft bij de markt (in samenwerking met het maatschappelijk midden); de overheid bekrachtigt de regeling. 
ning (door het Hof van Justitie) van de Europees-constitutionele waarde van een duurzame maatschappij een belangrijke, maar niet een noodzakelijke, voorwaarde. De weging van de belangen die aan de orde zijn - het marktbelang en het niet-economische belang - is immers gewaarborgd in het Verdrag. Zo'n weging moet in ieder geval geëxpliciteerd worden en kan langs bekende juridische mechanismen plaatsvinden. ${ }^{76}$ Een futuristische stap zou vervolgens een juridische inbedding van de ethische verplichtingen voor ondernemingen zijn, bijvoorbeeld als onderdeel van Europese burgerschapsverplichtingen. ${ }^{77}$ Dat vergt, toegegeven, nog wat juridische lenigheid, ${ }^{78}$ maar de erkenning van een eigen legitimiteit van afspraken tussen ondernemingen zou de mededingingsrechtelijke beoordeling van duurzaamheidsinitiatieven nog drastischer veranderen.

76. Dat betekent dat er, anders dan bij de toepassing van de uitzondering, geen kwantificering van negatieve en positieve effecten van een afspraak nodig is. Volgens sommigen is dat een voordeel: zo kan daadwerkelijke belangenafweging plaatsvinden, gebaseerd op een kwalitatieve weging van de verschillende betrokken belangen. De incommensurabiliteit van de belangen wordt niet gecamoufleerd door kwantificering, die een schijnobjectiviteit geeft. Aan de andere kant: het nadeel van niet-kwantificeren is volgens anderen dat daarmee het risico van 'greenwashing' van kartels wordt vergroot. Ook ontstaat het al eerder genoemde gevaar van subjectieve of politieke oordelen. Mij lijkt het probleem vooral dat kwantificering in het mededingingsrecht lijkt te zijn doorgeslagen van hulpmiddel naar doel op zich. Kwantificeren heeft als voordeel dat het besluitvorming helderder kan maken; inzicht in de kosten en baten van een afspraak misstaat ook niet in een kwalitatieve beoordeling. Maar zij zou vooral moeten dienen ter informering van de keuze, niet als doorslaggevende factor. Vooral om de economen gerust te stellen die soms weinig vertrouwen in juristen lijken te hebben voeg ik toch nog eens toe dat een weging geenszins ongeclausuleerd is (zie over weging o.a. R. Alexy, 'Constitutional Rights, Balancing, and Rationality', Ratio Juris (16) 2003, afl. 2, p. 131-140). Proportionaliteit kan bijvoorbeeld een belangrijk hulpmiddel zijn in een juridische toets (zie o.a M. Klatt en M. Meister, The Constitutional Structure of Proportionality, Oxford: Oxford University Press 2012), maar ook vindt, als de civil society serieus wordt genomen, een belangenafweging al voorafgaand aan een mededingingstoets plaats in het publiek domein, met eigen verantwoordingsmechanismen. Die toetsing in het publiek domein kan vervolgens als een toetsing van de 'governance' van een initiatief worden meegewogen (over dat laatste ook: J. Mulder, Social legitimacy in the internal market - a dialogue of mutual responsiveness (diss. Florence), Florence: European University Institute 2016). Verder in algemene zin over kwantificeren: H.S. Richardson, 'The Stupidity of the Cost-Benefit Standard', Journal of Legal Studies (29) 2000, afl. 2, p. 971-1003; C. Rose, 'Environmental Faust Succumbs to Temptations of Economic Mephistopheles. Or, Value by any other Name Is Preference', Michigan Law Review (87) 1989, afl. 6, p. 1631-1711, en over willingness to pay: M. Adler, 'Welfare Polls: A Synthesis', New York University Law Review (81) 2006, afl. 6, p. 1875-1970; D. LewinsohnZamir, 'Consumer Preferences, Citizen preferences, and the Provision of Public Goods', Yale Law Journal (108) 1998, afl. 2, p. 377-406.

77. Zie hiervoor over het concept corporate citizenship. De link met Europees burgerschap kan worden gelegd via marktburgerschap (zie bijvoorbeeld N.N. Shuibhne, 'The resilience of EU market citizenship', Common Market Law Review (47) 2010, afl. 6, p. 1597-1628); en via 'social citizenship' (T. Faist, 'Social Citizenship in the European Union: Nested Membership', Journal of Common Market Studies (39) 2001, afl. 1, p. 37-58). Burgerschapsverplichtingen zijn aan de orde bij R. Bellamy, 'Duty-Free Europe? What's Wrong with Kochenov's Account of EU Citizenship Rights?', European Law Journal (21) 2015, afl. 4, p. 558-565; en N.N. Shuibhne, 'Limits rising, duties ascending: The changing legal shape of Union citizenship', Common Market Law Review (52) 2015, afl. 4, p. 889-937.

\section{Slot}

Niet alle duurzaamheidsinitiatieven zullen passen in het hier geschetste kader. Maar ik heb ook niet alle mogelijk routes besproken. ${ }^{79}$ Ik verwacht dat de uitzondering van het derde lid - en dus de Beleidsregel van de minister voorlopig relevant blijft. Interessant is het dat de minister het voortouw heeft genomen in een verandering van interpretatie die bij de Europese Commissie nog niet lijkt te zijn ingezet. Diens interpretatie paste bij het marktdenken van de jaren tachtig en negentig van de vorige eeuw. Ondertussen is niet alleen de maatschappij veranderd, maar lijkt er ook iets verschoven in het economisch denken zelf. Het zijn die veranderingen die in het mededingingsrecht zullen doordringen. Ik waag mij tot slot op het terrein van Asimov en andere sciencefictionauteurs. $^{80}$

Dit is hoe het mededingingsrecht er over een decennium uit zou kunnen zien:

1. Een vólgende versie van de Beleidsregel van de minister kreeg een breder toepassingsbereik en werd gebaseerd op een fundamentele beschouwing over de grondslagen van mededingingsrecht in de economisch orde.

2. Het Hof van Justitie sprak zich in 2020 uit over de bestaansgrond van het Europese mededingingsrecht, noemde daarbij begrippen als solidariteit en een rechtvaardige samenleving, baseerde dat op de constitutionele inbedding van het mededingingsrecht in de Europese Unie als waardengemeenschap die is geves-

78. Die lenigheid kan gaan via het concept van transnational responsibility (L. Enneking, Foreign direct liability and beyond. Exploring the role of tort law in promoting international corporate social responsibility and accountability (diss. Utrecht), Den Haag: Eleven International Publishing 2012), het betrekken van onderzoek naar marktomstandigheden en collectieve actie (o.a. D. Spar \& D. Yoffie, 'A race to the bottom or governance from the top?', in: J.A. Hart en A. Prakash, Coping With Globalization, London: Routledge 2000, p. 30-51; D. Mügge, 'PrivatePublic Puzzles. Inter-firm competition and transnational private regulation', New Political Economy (11) 2006, afl. 2, p. 177-200; D. Baron, 'Morally Motivated Self-Regulation', American Economic Review (100) 2010, afl. 4, p. 1299-1329), en het leggen van een link naar onderzoek naar hoe marktomstandigheden kunnen leiden tot ethische verplichtingen (zoals: D. van der Ven en R. Jeurissen, 'Competing Responsibly', Business Ethics Quarterly (15) 2005, afl. 2, p. 299-317).

79. Zoals aangegeven: de verbreding van de voorwaarden van de uitzondering bleef hier buiten beschouwing; een herinterpretatie van de art. 106 VWEU-route (daarover o.a.: K. Lenaerts, 'Defining the concept of "services of general interest" in light of the "checks and balances" set out in the EU Treaties', Jurisprudence (19) 2012, afl. 4, p. 1247-1267, <Mruni. eu/upload/iblock/a8c/001_lenaerts.pdf>); of de exceptie van inherente beperkingen (zie het artikel van E.J. Kloosterhuis elders in dit nummer van $M \& M$ ) zijn andere opties. Of een Verdragswijziging natuurlijk.

80. Omdat dit de laatste voetnoot is, voeg ik als uitsmijter nog wat aanraders toe die voor juristen interessant zouden kunnen zijn: Alistair Reynolds's boeken (vanwege de enorme hoeveel verschillende typen overheids- en bestuursstructuren die de - soms vage, soms vlijmscherpe achtergrond vormen van zijn wereldenomspannende technologischhoogstaande space-opera's); Neal Stephenson's boeken (voor met name de verhouding tussen technologie en organisatie van de maatschappij, die de achtergrond vormt van o.a. The Diamond Age; Or, A Young Lady's Illustrated Primer (Bantham Books 1995) en Anathem (William Morrow \& Company 2008), en in een ietwat ander genre vanwege de milde satire en maatschappijkritiek, o.a. op corrumperende gevolgen van ongebreidelde macht, vrijwel alles van Terry Pratchett. 
tigd in een duurzame samenleving en een sociale markteconomie.

3. Het Hof van Justitie makte daarbij een zorgvuldige afweging tussen de belangen van concurrentie nú en het via samenwerking tussen ondernemingen waarborgen van de belangen van toekomstige generaties.

4. Daarbij werd de rol van civil society in de vormgeving van het publiek belang betrokken.

5. De Europese Commissie bleek ook al langer met het onderwerp te worstelen, en versnelde een intern voorbereide verandering in haar handhavingsbeleid als gevolg van het baanbrekende arrest van het Hof van Justitie.

6. Ook het Europees mededingingsrecht houdt tegen die tijd expliciet rekening met globalisering: ook verduurzaming elders, waarvan hier de kosten (kunnen) worden gedragen, kan worden geaccepteerd.

7. Dat ondernemingen zich het publiek belang niet alleen kunnen, maar onder omstandigheden ook moeten aantrekken, ook gezamenlijk, werd juridisch verankerd bij Verdragswijziging van 2025.

8. Nederland bleek derhalve op mededingingsrechtelijk vlak, anders dan in de vorige eeuw, een voorloper en werd inspiratiebron voor de vormgeving van mededingingsregimes elders. 